\title{
Marital Dissolution in Finland: Towards a Long-Term Perspective
}

\author{
KARI PITKÄNEN \\ Research Associate \\ Department of Economic and Social History \\ University of Helsinki
}

\section{Introduction}

During the past few centuries in Finland marriage has in most cases resulted in the formation of a new family unit. Among the farming population, however, newlyweds frequently started their married life by living with the husband's or wife's parents - or in some cases even with the siblings of one of the spouses, thus extending an already existing family unit.

The function of the family - or more narrowly put - of the married couple ${ }^{1}$ can be viewed from several angles. Traditionally one of the most important functions attached to the family has been that of procreation and the raising of offspring until the children are capable of starting a life of their own. In addition the family is - and has been - a manifold economic unit, which, within the societal context, has tried primarily to ensure the economic security of its own members.

The fulfilment of the above mentioned functions in a nuclear family would require the marriage to last a relatively long time. At first, it takes a considerable time until all the children are old enough to support themselves. When we take into consideration that during the past few centuries the mean age of women at the birth of their last child was relatively high all over Europe, ${ }^{2}$ it is clear that parents would be of an advanced age, and perhaps may have died, before all their children reached adulthood.

Secondly, economic security has been traditionally based on the fact that the father of the family has been the main provider. In urban laboring and middle-class families the wife used to take care of the home and the husband was the wage-earner. In such a case the loss of the father, especially if children were still relatively young, may have drastically affected the economic security of the surviving members of the family. The situation did not necessarily cause an immediate economic disaster, but surely led to a revaluation of the economic possibilities of the family and its individual members. Even in traditional (small-scale) farming, where both man and wife usually shared the farm work, the untimely loss of the husband undoubtedly shook the basis of family economy.

Since the Second World War the picture sketched above has considerably changed. The increased participation of married women in the (wage-earning) labor-force has made them economically more independent and less vulnerable. Advancements in the social security system have considerably improved the economic security of both adults and children where marital dissolution is concerned. However, it would be a great misjudgement to claim that the dissolution of a marriage no longer had deep consequences on the lives of the family members.

${ }_{1}$ In this paper such terms as the married couple and the family are in practice used interchangeably, although it oversimplifies the meaning of these expressions.

${ }^{2}$ Approximately 40 years of age for women who did not die before the end of their fertile period (see e.g. Flinn, 1981, Appendix Table 8). 
The purpose of these general considerations is to show that in order to give a meaningful interpretation to the demographic significance of marital dissolution in different societal surroundings, it should be related to the family (as well as the individual) life cycle. As it is self-evident that no marriage is indissoluble, interest should be focused on such questions as the interval between the wedding and the dissolution of marriage (the duration-specific approach), and the immediate cause of the dissolution (death of husband or wife, divorce). Also, the marriage patterns (including remarriage) as well as birth timing within the marriage should be examined. In fact, my long-term plans are to study both family formation and dissolution, although this paper only presents some preliminary findings strictly limited to the latter phenomenon.

\section{Materials and methods}

At this stage of the study I have only (with a few exceptions) made use of the published population statistics, plus use of unpublished tables and so called working tables (which might be thought of as »semi-finished» population statistics) produced by the Central Statistical Office of Finland.

Up-to-date Finnish statistical materials allow a very detailed analysis of nuptiality, e.g. even a construction of such multi-state (or increment-decrement) nuptiality or marital-status (life) tables presented by Schoen and Nelson in 1974, and by using a different approach, by Willekens et al. in 1982. From the historical point of view, adequate opportunities to study family formation have been available since the late 19th century. However, the chances of providing a long-term perspective on marital dissolution by utilizing official statistical data has proved to be less encouraging.

As is well-known, the collection of proper nationwide population statistics was begun both in Sweden and Finland (an eastern part of Sweden up to 1809) in the middle of the 18th century. Information concerning the number of marriages dissolved through death of one of the spouses was collected from the very beginning, but even this scarce information was not published prior to 1859 .

The Central Statistical Office of Finland started to collect and publish statistical information concerning divorces from 1878 onwards (see OSF VI:6, 6). Except for the grounds for divorce the only piece of information provided by the official population statistics prior to the 1930 s is in practice the yearly number of divorces. Not only is this information scarce, but it even seems slightly to underestimate the true number of divorces up to 1930 (Mahkonen, 1980, 11-18).

In the 1920 s and 1930 s information provided by population statistics concerning the dissolution of marriages became somewhat more plentiful, but it was not until the beginning of the 1950 s that Finnish population statistics could meet the challenge of a more ambitious examination of marital dissolution. An important amendment in the statistics was to classify dissolved marriages according to the year of marriage into three groups: dissolved by death of the husband, by death of the wife, and by a divorce decree.

The scarcity of statistical materials has greatly affected the contents of this paper. Most results presented here are from the period after the Second World War, and only some very general data are presented from the earlier period. Thus, from a historian's point of view the attempts to come up with a long historical perspective are not yet fulfilled. A more systematic approach, however, will be possible in the future, after the sex-specific life tables (which are being constructed by the author for 18 th and 19th century Finland) are completed. ${ }^{3}$

The methods used in this paper are standard, conventional methods used in demographic analysis. Part of the results presented here are derived from a cohort analysis based on certain marriage cohorts from the period between 1930 and 1975 .

${ }^{3}$ For the use of life tables see e.g. Hansen (1981). 
Marital dissolution of these cohorts has been analyzed by using an ordinary double decrement (life) table. The tables are computed by duration of marriage in single years and they allow attrition both due to death of one of the spouses and divorce. Both these types of withdrawal from life table populations are treated in the same way, i.e. decrements through divorce are computed »in presense» of deaths, and vice versa. In addition to this, attrition due to divorce has also been computed »in absense» of deaths. ${ }^{4}$ In the latter case the assumption is that the probability of divorce would have been the same for those marriages which were dissolved by death as for those marriages in which both of the spouses lived until the end of the follow-up period. This assumption may not be totally acceptable, since it is clear that especially during the first ten or twenty years of marriage (except during wartime) dissolutions through death were naturally mainly found in marriages where the spouses were on average older. It seems that the probability of divorce within these marriages was smaller than in those marriages where the spouses had married at an early age (see below).

Space does not permit me to give here the computed marriage dissolution tables, or the details of other results. I shall, however, present some of the central results, mainly in the form of graphs.

\section{General features of development}

Rates of marital dissolution by death and divorce for the last 130 years are depicted in Figure 1. Although the population statistics probably somewhat underestimate the real number of divorces prior to 1930, it is clear that the role of divorces in marital dissolution was practically non-existent up to the beginning of this century.

One might try to explain the small number of divorces by pointing out that although divorce was legalized in Finland as early as the 16th century, after the reformation of the Roman Catholic Church, divorces were not easily granted. Up to 1930 , when the new divorce law (a section of the marriage law) came into operation, the possible legal grounds for divorce were above all adultery and wilful desertion - but not marital discord (Anttila, 1977, 9-10; Mahkonen, 1981, 1-2).

It was not, however, strict legislation per se that kept the number of divorces small. From the 17th century onwards divorce was also granted through an exemption procedure (based on free deliberation by the deciding body ${ }^{6}$ ). This possibility began to be used more and more in the early 20 th century, and due to the exemption procedure, marital discord gradually gained a significant position among the grounds for divorce (Anttila, 1977, 10; Mahkonen, 1981, 75-77, 112-127). Also divorces granted on legal grounds became much more common at the turn of this century than they used to be, especially prior to the middle of the 19th century. These developments took place at the same time when Finnish society was experiencing thorough changes due to the industrialization and urbanization process. Thus, it seems clear that it was not legislation itself, but the societal changes (and the changing attitudes related to this process), which primarily affected the frequency of divorces. It is also noteworthy that already in the 1920 s divorces were relatively more frequent in the urban municipalities than in the rural areas during the 1950s and 1960s (Figure 2,

4 In this case the divorce probabilities for each interval have also been computed by assuming that marriages dissolved through death during the interval have been potentially subject to divorce for on average only half of the interval.

5 Double decrement nuptiality or marriage dissolution tables have been computed by several authors. See e.g. Grabill (1945) and Saveland-Glick (1969) (first-marriage tables); Jacobson (1959) (marriage dissolution table). These works also present the general methodological approaches to the construction of these kinds of double decrement tables.

6 During the Swedish period the King, during the Russian period at first the Emperor, from 1826 onwards the Senate, during the period of independence the Supreme Court (up to 1930) (Allardt, 1953, 26; Mahkonen, 1980, 29-33). 
F i g u r e 1. Marital dissolutions by death and divorce per 1,000 married women, Finland, 1851-1982.

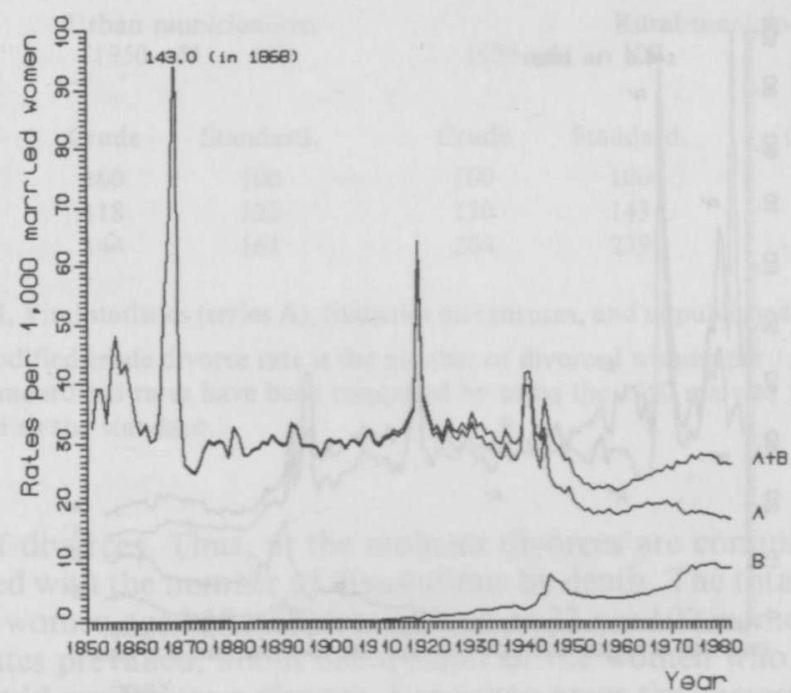

$\mathrm{A}=$ Deaths $\mathrm{B}=$ Divorce

Sources: OSF VI, Vital statistics 1865-1981 (series A), Statistics on censuses from 1865 to 1940, and unpublished tables for 1982; Deanary level population change tables in the Central Statistical Office 1851-1877; Statistical Yearbook of Finland; Divorce rates for 1851-1885 are based on the material collected by Sami Mahkonen.

p. 64). In fact, several authors have pointed out that the new 1930 divorce law should be viewed as an adjustment to a development which had already taken place within society and in the actual exercise of the law (Allardt, 1953; Anttila, 1977; Mahkonen, 1980).

It is clear, however, that especially in the past the number of divorces does not totally reflect the »true» number of broken marriages. There have undoubtedly always been marriages in which the spouses were no longer cohabiting. There is obviously no way of finding out the number of such de facto separated spouses (judicial separation has been possible since 1948), but one should be careful not to overestimate their significance in the agrarian Finnish society. These separations may have become somewhat more frequent after the beginning of industrialization, when the diversification of economic possibilities (one possibility being emigration) and diminished controls from the local communities made separation easier. On the other hand, it is possible that most of these separations sooner or later resulted in a legal dissolution of the marriages.

At first glance, it might look curious that the dissolution rates by death do not show any clear tendency to decrease from the 1870 s to the late 1940 s, except for cities, where rates decline to a slightly lower level at the turn of this century. Partly this constant development is due to the fact that in Finland the average adult mortality did not exhibit any considerable changes between the 1870 s and the mid-1940s. On the other hand, one must bear in mind that the rates used are crude in the sense that they are liable to changes in the age composition of the married population. Starting at the turn of this century the proportion of married people considerably decreased, especially in the rural areas (see Pitkänen, 1981), and this led simultaneously to the ageing of the married population (OSF VI, Statistics on censuses 1880-1940). 
F i g u r e 2. Marital dissolution by death and divorce per 1,000 married women, Finland, urban and rural municipalities, 1851-1982.

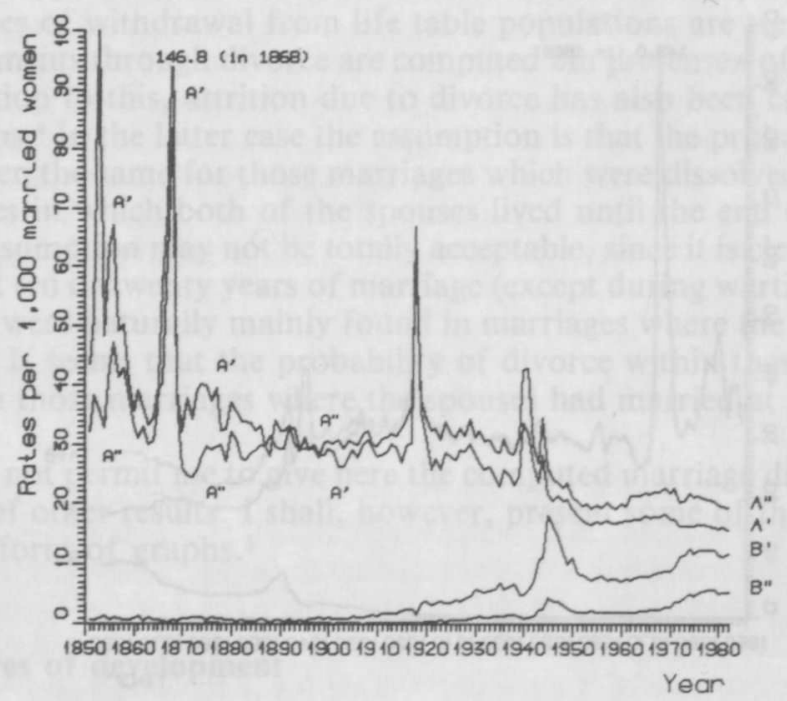

$\mathrm{A}=$ Deaths $\mathrm{B}=$ Divorce

= Urban municipalities " = Rural municipalities

Sources: OSF VI, Vital statistics 1865-1981 (series A), Statistics on censuses from 1865 to 1970, and unpublished tables in 1974-79 and 1982; Hultin 1924; deanary level population change tables in the Central Statistical Office 1851-1877; Divorce rates for 1851-1889 are based on the material collected by Sami Mahkonen.

In the late 1940 s and early 1950 s adult mortality, especially mortality of young adults began to decline rapidly. In addition nuptiality increased after the Second World War resulting in a younger married population. The fast decline in the dissolution rates by death starting in the late $1940 \mathrm{~s}$ is due to both of these factors. After this rapid change the married population started to grow older again and dissolution rates by death have remained nearly constant since the 1950 s. Divorce rates, however, have increased considerably since the late 1960 s, and the contribution of divorces to the total of marital dissolutions is greater than ever before. Divorce accounted for $0.2-0.7$ percent of marital dissolutions between the 1850 s and the $1880 \mathrm{~s}$, whereas the corresponding proportion was $4.0 \%$ in the $1920 \mathrm{~s}, 18.3 \%$ in the $1950 \mathrm{~s}$, and $32.8 \%$ in the $1970 \mathrm{~s}$. At the moment the annual total dissolution rates are almost as high as at the turn of the century.

Rural-urban differentials are, however, considerable. Especially since the 1920s the contribution of divorces to the total of marital dissolutions has been significantly larger in urban than in rural municipalities. In the 1970s the proportion of divorces in marital dissolutions was 41.8 percent in urban areas, and only $19.0 \%$ in rural areas. These differentials are to some extent due to the differences in the age composition of the married population. Since the early 20 th century the mean age of the married population has been clearly lower in urban than in rural areas, and this has been the main reason for differences in the dissolution rates by death. The same factor has also contributed to the higher dissolution rates by divorce in the cities, but only to a small extent. Table 1 presents a comparison of the »modified crude» and agestandardized divorce rates. The indexes clearly show that the divorce rates are still today considerably higher in urban areas, even according to the standardized rates.

In addition, the comparison reveals that due to the changes in the age composition of the married population the crude rates somewhat underestimate the growing 
$\mathrm{T}$ a b l e 1. Comparison of the modified crude and age-standardized divorce rates, Finland, urban and rural municipalities (married female population).

\begin{tabular}{lcccccc} 
& $\begin{array}{c}\text { Urban municipalities } \\
1950-51=100\end{array}$ & \multicolumn{2}{c}{$1950-51=100$} & $\begin{array}{c}\text { Rural } \\
\text { Urbanicipalities } \\
\text { Ununicipal. } \\
=100\end{array}$ \\
Years & Crude & Standard. & Crude & Standard. & Crude & $\begin{array}{c}\text { Standard. } \\
1950-51\end{array}$ \\
$1970-71$ & 100 & 100 & 100 & 100 & 36 & 38 \\
$1980-81$ & 118 & 122 & 130 & 143 & 40 & 44 \\
& 144 & 161 & 204 & 239 & 51 & 56
\end{tabular}

Sources: OSF VI, Vital statistics (series A), Statistics on censuses, and unpublished tables for 1979-81.

Note: The modified crude divorce rate is the number of divorced women per 1,000 married women. The standardized rates have been computed by using the 1950 married female population of Finland as the standard.

significance of divorces. Thus, at the moment divorces are common, and not only when compared with the number of dissolutions by death. The total divorce rate for 1980 - 81 (for women aged 15-69) was as high as 27 per 100 women. Thus, if these age-specific rates prevailed, about one quarter of the women who were of the ages mentioned would experience a divorce. For urban areas the corresponding rate was $32 \%$.

In a divorce both of the spouses, in a sense, are in an equal position - they both survive. However, when a marriage dissolves because of death, this of course is not true. Figure 3 (p. 66) shows the sex-specific dissolution rates by death.

During the latter half of the 19th century the sex-specific differences in marital dissolution by death were not particularly large. In 44 cases out of a hundred the deceased spouse was the wife. This difference is understandable since the median age at marriage was somewhat higher for males and the life expectancy of the adult male population was slightly lower. ${ }^{8}$

Since the early 20th century a larger and larger proportion of widowed persons have been females. In the 1970 s their proportion was 74 percent, compared with less than $60 \%$ in the late 19 th century or $61 \%$ in the 1920 s. This development seems to be almost exclusively due to the increased male excess mortality, since no considerable changes in the age difference between newly-weds have taken place. ${ }^{9}$

\section{Age and marital dissolutions}

We have seen that the increased number of divorces has to a considerable extent counterbalanced the decline in the dissolution rates by death. The counterbalancing effect is not, however, limited to the numbers of dissolutions. Since it is known that divorces are concentrated in the younger age groups of the married population, it is plausible that the increase in divorce rates has reduced the favourable effect of declining mortality among the marriages of young adults. In order to give a general view of this change age-specific divorce and death rates for the married population

7 The total divorce rate (TDR) is analogous to the total fertility rate, and the age-specific divorce rates have been added up without weighting. The total population not the married population has been used as denominators of the ages in question (see Shryock-Siegel, 1980, Vol. 2, 573). It should also be noticed that the TDRs presented here include divorces of all orders. However, it is not very likely that a very considerable proportion of the population would have several divorces.

${ }^{8}$ E.g. in $1881-91$ life expectancy at the age of 20 was 41.5 years for males and 43.3 years for females (OSF VI: 33 ).

${ }^{9}$ E.g. in $1971-75$ life expectancy at the age of 20 was 48.4 years for males and 56.4 years for females (Statistical Yearbook of Finland 1982). 
F i g u r e 3. Sex-specific marital dissolution rates by death per 1,000 married women, Finland, 1851-1982.

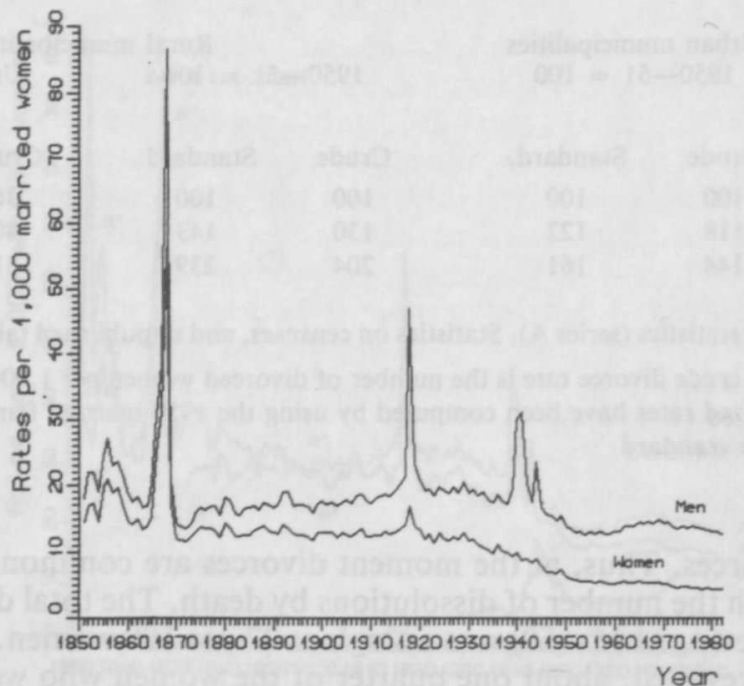

Sources: See Figure 1.

Note: The numbers of married men and married women differ somewhat in the statistics. The differences, however, are so small that the rates for both sexes have been computed by using the numbers of married women.

F i g u r e 4. Age-specific death and divorce rates for the married female population, Finland, 1936-40 and 1980-81, five-year age groups.
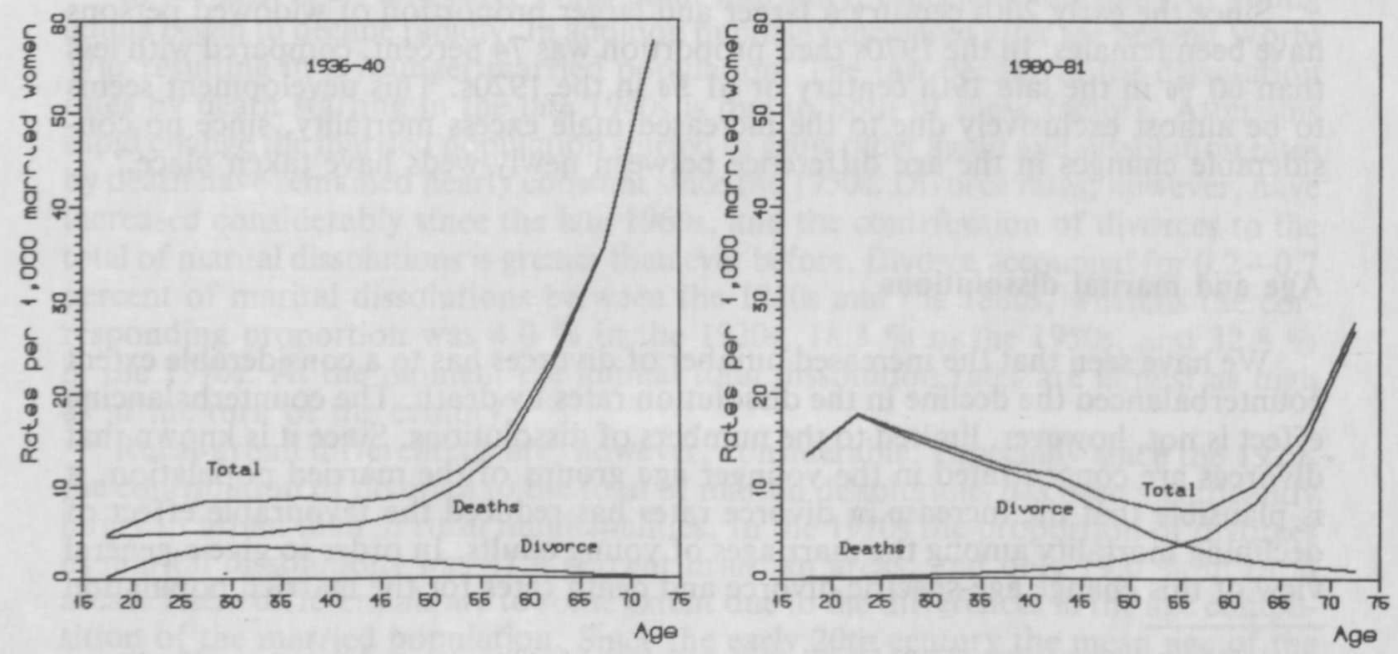

Sources: OSF VI, Vital statistics (series A), Statistics on censuses (1930 and 1940). 
have been computed. These rates have been depicted in Figure 4 for two periods. Only rates for the female population have been presented here.

Especially if one takes into account the fact that marriages were also dissolved through the death of the husband it is obvious that prior to the Second World War marital dissolutions by death played a much more important role than divorces, even among young couples. At the turn of the 1980 s the situation was exactly the opposite. Although mortality among young adults is very low at the moment, it is plausible that for young couples marital dissolution is nowadays approximately as common as it was prior to the great mortality decline which started in the late 1940s. However, today, it is more common for both of the spouses to survive and remarry in cases of marital dissolution.

\section{The cohort approach}

The cohort analysis of marital dissolution includes eleven marriage cohorts. In addition to analyzing marriages contracted every fifth year during the period $1930-1975$, the marriage cohort of 1942 has also been included in the analysis. ${ }^{10}$ The 1942 cohort is of special interest, since as early as 1951 Tunkelo pointed out that even among so-called wartime marriages divorce rates were exceptionally high for this marriage cohort.

There is one obvious problem, when marital dissolution is compared among different marriage cohorts. Differences in the duration-specific rates may reflect not only »real time-specific» changes but also changes in the age composition of the newlyweds. As far as the cohorts studied are concerned this is not merely a theoretical problem, as can be seen from the following classification of brides by age at marriage (figures are given in percentages): ${ }^{11}$

$\begin{array}{lccccc}\begin{array}{l}\text { Marriage } \\ \text { cohort }\end{array} & \begin{array}{c}\text { less than } \\ 20 \text { years }\end{array} & 20-29 & \begin{array}{c}\text { Age group } \\ 30-39\end{array} & 40+ & \text { Total } \\ 1930 & 12.0 & 67.6 & 14.5 & 5.9 & 100 \\ 1935 & 9.7 & 69.3 & 15.8 & 5.2 & 100 \\ 1940 & 10.3 & 64.2 & 19.3 & 6.3 & 100 \\ 1942 & 10.3 & 63.4 & 19.7 & 6.7 & 100 \\ 1945 & 10.2 & 64.3 & 18.9 & 6.6 & 100 \\ 1950 & 15.3 & 62.7 & 14.4 & 7.6 & 100 \\ 1955 & 18.5 & 63.3 & 11.3 & 6.9 & 100 \\ 1960 & 20.9 & 62.7 & 10.2 & 6.2 & 100 \\ 1965 & 29.4 & 57.5 & 7.8 & 5.3 & 100 \\ 1970 & 21.8 & 67.0 & 6.6 & 4.6 & 100 \\ 1975 & 18.0 & 70.7 & 7.5 & 3.9 & \end{array}$

The general trend visible in the figures is that the mean age at marriage has declined. Considering a comparison of cohorts this means that in the older cohorts dissolutions by death are probably emphasized at the expense of divorces. The opposite holds true for the younger cohorts (the trend was similar concerning the age of bridegrooms, too).

10 Marital dissolutions by death and divorce according to duration of marriage have been published in the official population statistics since 1952. For the earlier period, data concerning divorces have been partly obtained from Tunkelo (1951), partly from the working tables of the Central Statistical Office. For some years the number of divorces had to be calculated from the lists of divorces sent by the Courts of Justice to the Central Statistical Office. The number of deaths had to be estimated for the period prior to 1952 , but the method of estimation is too complicated to be presented here. Unfortunately, it has not been possible to take into account decrements due to emigration.

11 OSF, Vital statistics (series A). 
As was to be expected, cohort analysis revealed the decreasing significance of death and the increasing significance of divorce in marital dissolution (Figure 5). At the end of each yearly duration the contribution of deaths to total marital dissolution is significantly larger for older (1930-1942) than for younger cohorts. Although the significance of divorce considerably increased for the youngest cohorts (1960-1970 in Figure 5) the proportion of total marital dissolutions has remained much smaller at each duration compared with the older cohorts.

F i g u r e 5. Proportion of dissolved marriages by death and divorce at the end of certain durations, Finland, ten marriage cohorts (1930-1970).
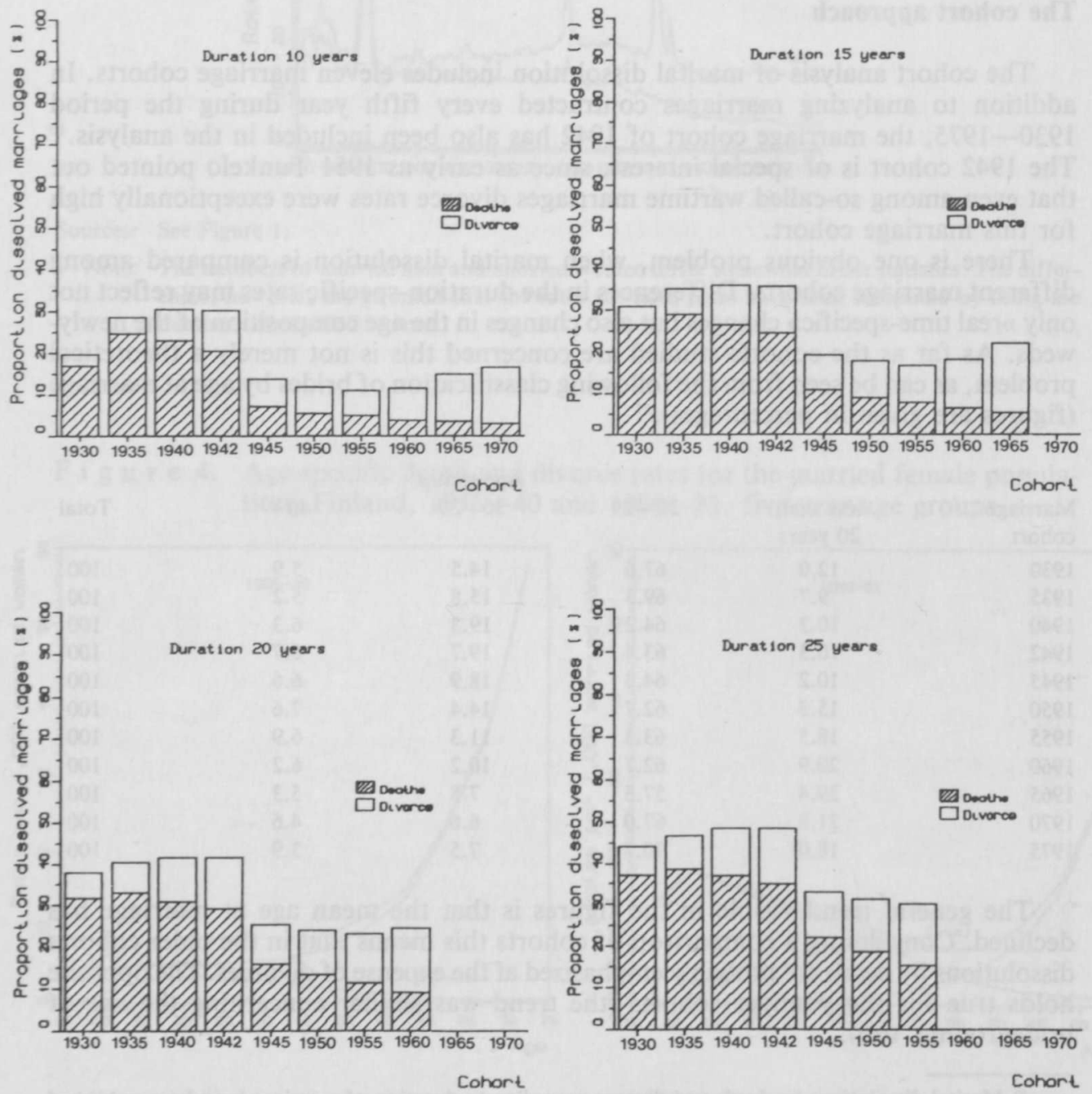

Sources: See footnote 10 above.

Note: The number of divorces is obtained from the year of marriage. Thus, a more »exact» duration is actually ten and a half years, fifteen and a half years, etc, since at the end of the year of marriage the real average duration of the marriages is approximately half a year. 
The fact that the older cohorts have married on average at a more advanced age, is undoubtedly one reason for the large differences regarding the role of mortality in marital dissolutions. Much more significant, however, is the war. All the older cohorts lived through the Second World War with high marital dissolution rates by death. Thus, if one wishes to find out the differences between older »normal» and modern times, the cohorts are not comparable. Besides, since one cannot follow the younger cohorts for any considerable period of time, a question arises, should one examine synthetic cohorts rather than real cohorts, i.e. use more easily accessible period data. In this way one could study marital dissolution under »normal» conditions at different times.

However, it must be emphasized that not very many marriage cohorts have experienced only so called normal times during the past centuries. In the past the norm was rather that marriage cohorts were often affected by more or less severe demographic crises.

\section{Divorce rates by cohort}

For my final object of analysis I would like to draw attention to the durationspecific divorce rates. These rates for the eleven cohorts have been depicted in Figure 6 . The shape of the curves differs considerably from one cohort to another, and

F i g u r e 6. Divorce rates per 1,000 marriages existing at the beginning of each duration, Finland, eleven marriage cohorts (1930-1975).
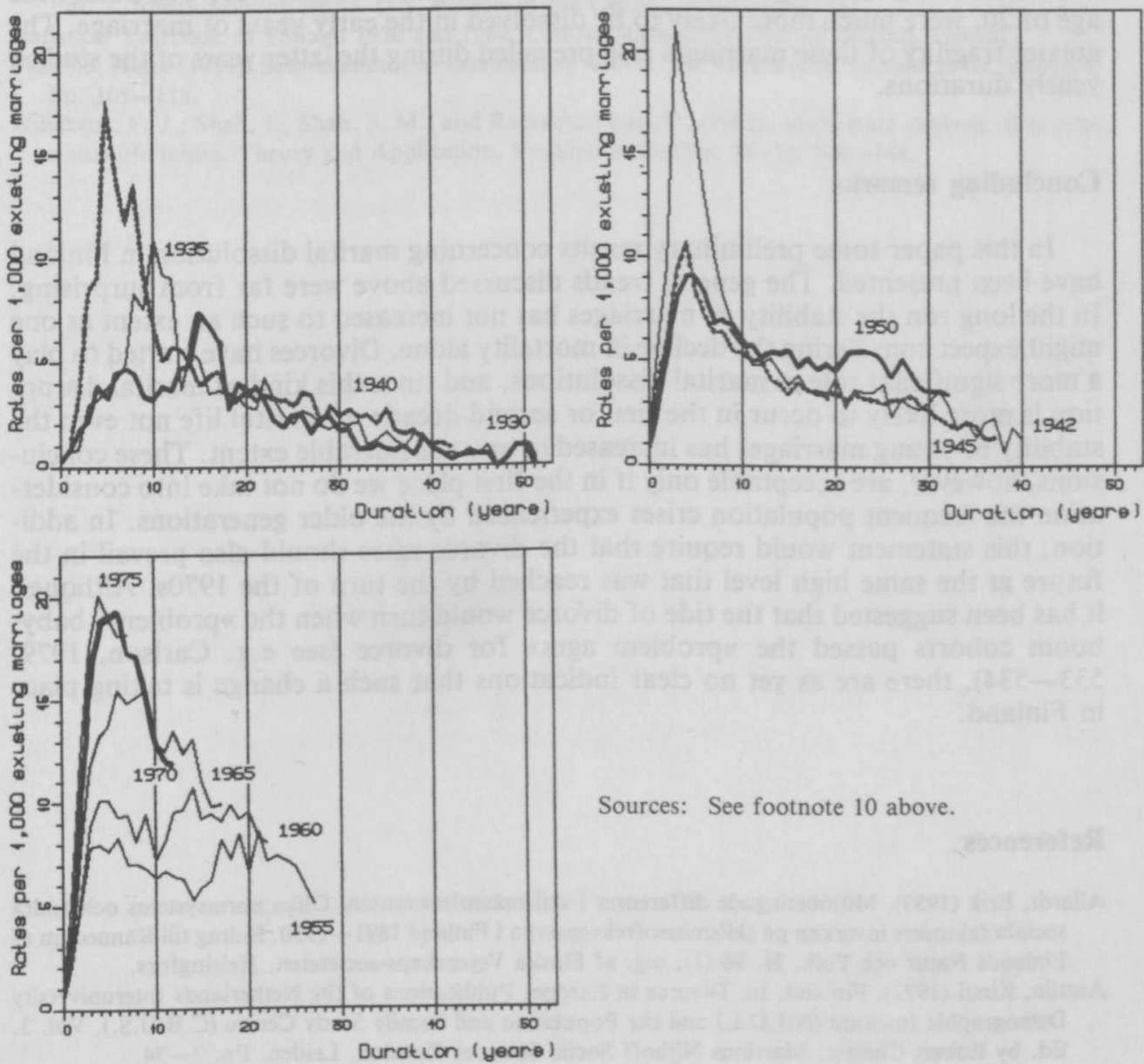

Sources: See footnote 10 above. 
especially the peak periods of divorces take place at different durations. This phenomenon would require further investigation, but the fluctuations in the divorce rates would seem to imply that certain time-periods have had a considerable effect on the behavior of the different cohorts. As we have seen (Figures 1 and 2) there have been two major peak periods in the number of divorces, the first in the middle of the 1940s, the other in the 1970s (it is still going on). Those marriages contracted either simultaneously with, or just prior to the peak periods show the highest figures for the duration-specific divorce rates. But, the effect of these periods can be clearly seen in other cohorts, too. For example, the 1930 and 1935 cohorts show the highest values in the middle of the 1940s. In a same way, although not quite so clearly, a rise in the divorce rates is visible for the 1950, 1955, and 1960 cohorts when these marriages enter the 1970 s.

Thus, the marriages contracted during the Second World War or in the 1970s have no monopoly on the high divorce rates, although their contribution to the rise in divorce has been considerable. Although it is plausible that there is some kind of a typical divorce schedule for the marriage cohorts (relatively rapid increase during the first 3-8 years of marriage, after that a slow decline), certain periods in societal development may considerably change it.

It is also noteworthy that although certain cohorts have experienced extremely high divorce rates during the first years of marriage, these marriages were also equally likely to end in divorce during the latter years of the period studied when compared with the preceding (or following) cohort(s) with less dramatic beginning. Similar kind of results were also obtained when some of the marriage cohorts examined were classified according to the age of bride. Marriages in which women were wed before the age of 20 , were much more likely to be dissolved in the early years of marriage. The greater fragility of these marriages also prevailed during the latter years of the studied yearly durations.

\section{Concluding remarks}

In this paper some preliminary results concerning marital dissolution in Finland have been presented. The general trends discussed above were far from surprising. In the long run the stability of marriages has not increased to such an extent as one might expect considering the decline in mortality alone. Divorces have started to play a more significant role in marital dissolutions, and since this kind of marital disruption is more likely to occur in the first or second decade of marital life not even the stability of young marriages has increased to any considerable extent. These conclusions, however, are acceptable only if in the first place we do not take into consideration the frequent population crises experienced by the older generations. In addition, this statement would require that the divorce rates should also prevail in the future at the same high level that was reached by the turn of the 1970s. Although it has been suggested that the tide of divorce would turn when the »problem» babyboom cohorts passed the "problem ages» for divorce (see e.g. Carlson, 1979, 533-534), there are as yet no clear indications that such a change is taking place in Finland.

\section{References}

Allardt, Erik (1953). Miljöbetingade differenser i skilsmăssofrekvensen. Olika normsystems och andra sociala faktorers inverkan på skilsmässofrekvenserna i Finland 1891-1950. Bidrag till Kännedom af Finlands Natur och Folk, H. 96 (1), utg. af Finska Vetenskaps-societeten, Helsingfors.

Anttila, Kirsti (1977). Finland. In: Divorce in Europe. Publications of the Netherlands Interuniversity Demographic Institute (N.I.D.I.) and the Population and Family Study Centre (C.B.G.S.), Vol. 3, Ed. by Robert Chester. Martinus Nijhoff Social Sciences Division, Leiden. Pp. 7-34. 
Carlson, Elwood (1979). Divorce rate fluctuation as a cohort phenomenon. Population Studies, 33 (3): $523-536$.

Flinn, Michael W. (1981). The European demographic system 1500-1820. (Pre-Industrial Europe; no. 5). Harvester Press, Brighton.

Grabill, Wilson H. (1945). Attrition life tables for the single population. Journal of the American Statistical Association, 40 (231): $364-375$.

Hansen, H. O. (1981). The Importance of remarriage in traditional and modern societies: Iceland during the eighteenth and nineteenth centuries, and the cohort of Danish women born between 1926 and 1935. In: Marriage and remarriage in populations of the past, Ed. by J. Dupâquier, E. Hélin, P. Laslett, M. Livi-Bacci and S. Sogner. Academic Press, London. Pp. 307-324.

Hultin, Tekla (1924). Avioerot Suomessa v. 1922. In: Tilastokatsauksia 1924: 10, Central Statistical Office of Finland, Helsinki.

Jacobson, Paul H. (1959). American marriage and divorce. Rinehart \& Company, New York (in collaboration with Pauline F. Jacobson).

Mahkonen, Sami (1980). Avioero. Tutkimus avioliittolain erosäännősten taustasta ja tarkoituksesta. Suomalaisen lakimiesyhdistyksen julkaisuja A: 149, Vammala.

Official Statistics of Finland (OSF), Series VI (population statistics), Central Statistical Office of Finland.

Pitkänen, Kari (1981). Avioitumiskäyttäytymisen muutokset teollistuvassa Suomessa. In: När samhället förändras - Kun yhteiskunta muuttuu (Historiallinen Arkisto 76), Suomen Historiallinen Seura, Helsinki. Pp. 275-300.

Saveland, Walt; and Glick, Paul C. (1969). First-marriage decrement tables by colour and sex for the United States in 1958-60. Demography, 6 (3): 243-260.

Schoen, Robert; and Nelson, Verne E. (1974). Marriage, divorce and mortality: a life table analysis. Demography, 11 (2): 267-290.

Shryock, Henry S., Siegel, Jacob S.; and Associates (1980). The methods and materials of demography. Vol. 2, fourth printing (rev.). U.S. Bureau of the Census, Washington, D.C.

Statistical Yearbook of Finland 1950 and 1982, Central Statistical Office of Finland, Helsinki.

Tunkelo, Aarre (1951). Sota-avioliitot avioerotilaston valossa. In: Väestöliiton Vuosikirja III. Helsinki. Pp. $105-118$.

Willekens, F. J.; Shah, I., Shah, J. M.; and Ramachandran, P. (1982). Multi-state analysis of marital status life tables: Theory and Application. Population Studies, 36 (1): 129-144. 